\title{
An Iconographic Analysis of Photographs of Two Famous Football Players: Additional Information about the Career of Puskás and Deák
}

Authors' contribution:

A) conception and design of the study

B) acquisition of data

C) analysis and interpretation of data

D) manuscript preparation

E) obtaining funding

\section{H. Attila Horváth}

University of Pannonia, Hungary

ABSTRACT

The lifestyle reform movements at the turn of the century played a remarkably important role in the growing priority attributed to physical education. Sports clubs could be considered the most influential nongovernmental organizations at the beginning of the $20^{\text {th }}$ century. Sports were given special priority and were even supported by legal measures in Hungary between the two world wars. Playing football gained vast popularity. We focus on two famous football players, Puskás, "the most famous Hungarian" and Deák, a Guinness record-holding top goal scorer. To be precise, we focus on their photos: we have similar ones of a young Puskás and a young Deák. These photos depict a very important moment in the lives of both youngsters. We conduct an iconographic analysis in order to illustrate connections the two young football players have to their clubs and to the sport.

KEYWORDS iconographic analysis, informal learning, non-governmental organization, sports club, Puskas

\section{Introduction}

\section{Problem and aim}

Sports clubs could be considered the most influential nongovernmental organizations at the beginning of the $20^{\text {th }}$ century (Glatz 2003). Their establishment represented an expression of identity for the people living in the given settlement, and later on, as a result of their operation, this identity was constantly formed (Hadas \& Karády 1995, pp. 89-110). Sports clubs and associations were flourishing mostly in urban environments, due to the fact that sports became some of the most important free time activities all over the world. Playing football gained vast popularity (Romsics 2005, p. 100).

The lifestyle reform movements at the turn of the century played a remarkably important role in the growing priority attributed to physical education. These movements had a deep impact on pedagogical reforms and in physical education lessons at school. "The trends seeking a new lifestyle were all influenced by romanticism and had the same basic motif; a longing for the return to nature and to natural living conditions". A good example of the "reform euphoria of the time and that of tendencies among European youth for aspirations towards emancipation is a German youth movement called Wandervogel" starting around 1900 (Németh \& Skiera 1999, pp. 50-51). 
Sports were given special priority and were even supported by legal measures between the two World Wars in Hungary ${ }^{1}$. The reason for this decision was Hungary's difficult position after the Peace Treaty of Trianon $^{2}$. The government turned to education as a possible break out point from the situation and increasingly subsidized sports life and physical education.

Budapest, a newly acknowledged world capital of sports, took the leading role. The first football clubs were founded there and they started to mushroom. The model was then followed by smaller towns. It is worth taking a closer look and analyzing how sports clubs and associations came into existence there, how they were operated, and how the particular micro-environment influenced boys' informal learning processes and their future careers as football players. We focus on two sportsmen - how they started their career - who are iconic football heroes, namely Ferenc "Öcsi” Puskás ${ }^{3}$, "the most famous Hungarian," and Ferenc Deák a Guinness record-holding top goal scorer.

Deák and Puskás were connected to their town via a sports club, too: the former to Szentlörinci Atlétikai Club (SZAC), the latter to Kispest (KAC). The aim of this article is to illustrate their connections to their clubs and to the sport through iconographic analysis. The photos preserve the quotidian elements and evident details of life (Mietzner \& Pilarczyk 2010), which can specify the picture of both sportsmen's characters.

We have a similar photo of both young Puskás and young Deák taken at the beginning of the $1940 \mathrm{~s}^{5}$. The photos depict a very important moment in both youngsters' lives. Ferenc Deák had started to play on the SZAC first division team. Puskás joined the KAC junior team from his previous pre-junior team, and at the age of 14, he became a member of the Junior National Eleven. Deák's stamina was well reflected in the fact that he was even able to play three matches in the same weekend; one in the junior team, one in the back-up team, and one in the first division team at the age of 19 (Pongrácz 1992, pp. 12-15).

Both photos chosen for iconographic analysis were taken in similar locations and situations. Both pictures depict Deák and Puskás as members of a specific group of people. No data is available for the photographers. The photos were unpublished those days. They were taken from the biographies of the two footballers, which were published in 1992 and 2001, respectively.

\section{Two settlements - two sports clubs}

Investigating these two players we can see two settlements near the capital city: Kispest and Pestszentlőrinc.

Kispest became a major destination for domestic migration, due to its location ${ }^{6}$. Demographic statistics illustrate this tendency very clearly. According to statistical data, the pace of population growth in Kispest was much faster than that of any other similar-sized settlements with over 10,000 inhabitants. The number of

\footnotetext{
${ }^{1}$ The 1921. LIII. article about physical education.

2 "Hungary was deprived two-thirds of its rail, road and canal networks and $80 \%$ of its forests and mines." The Versaille peace treaty annexed approximately three million Hungarians from their home country. "These punishments were much stricter than those given to the major enemy, Germany" (Cartledge 2009, p. 90).

${ }^{3}$ Ferenc Puskás (1927-2006) was one of the best football players of all times. He started his career playing for Kispesti Atlétikai Club (KAC) and Budapest Honvéd. During the 1950s, he was both a prominent member and the captain of the Hungarian National Eleven known as the Golden Team, or Mighty Magyars. He scored 84 goals in 85 international matches of the Hungarian National Eleven. In 1958, two years after the Hungarian Revolution, he emigrated to Spain where he played for Real Madrid.

${ }^{4}$ Deák Ferenc (1922-1998): played for Szentlőrinci Atlétikai Club (SZAC), Ferencvárosi Torna Club, then Budapest Dózsa. He played on the Hungarian National Eleven 20 times.

${ }^{5}$ In 1941 there were nine sports clubs existing both in Kispest and in Pestszentlörinc (História-Térképek-V. História, 2003, pp. 8-9).

${ }^{6}$ Kispest is situated near the capital. In 1872 the municipality was small in size. In 1874 it became a bigger settlement but still not a town. People were attracted to move there because the capital city was close, but the cost of living was reasonable. Kispest was given a town status in 1922 while having 52,000 inhabitants.
} 
restaurants registered in Kispest shows another of its characteristics: it had approximately 120 restaurants five years after it had been given the status of town (Horváth 2011). According to accessible data, and supposing that the pace of population growth equaled growth that occurred between 1910 and 1922, we can claim that fewer than 500 inhabitants were able to frequent the same restaurant. Although some restaurants could also rely on customers from Budapest, most catering establishments were run by families whose source of income was provided by the guests from the immediate environment.

Table 1. Population growth in settlements with over 10,000 inhabitants (1900-1910)

\begin{tabular}{llllc}
\hline $\begin{array}{c}\text { Name of the } \\
\text { settlement }\end{array}$ & In 1900 & In 1910 & $\begin{array}{l}\text { Growth } \\
\text { Absolute } \\
\text { Growth }\end{array}$ & $\%$ \\
\hline Kispest & 9804 & 30212 & 20408 & 208.2 \\
Rákospalota & 11594 & 25147 & 13553 & 116.9 \\
Erzsébetfalva & 15732 & 30970 & 15238 & 96.9 \\
Petrozsény & 7765 & 12193 & 4428 & 57.0 \\
Soroksár & 8871 & 13345 & 4474 & 50.9 \\
Budafok & 7273 & 10.954 & 3681 & 50.6 \\
[Pestszentlörinc] & - & {$[7824]$} & & \\
\hline
\end{tabular}

[61 Hungarian medium-sized settlements are part of the statistics. In our table, we have only listed those with a 50\% population growth and added the population of Pestszentlörinc (Magyar Statisztikai Évkönyv 1910, p. 15)].

Restaurants also played an important role in the life of sports clubs. The Kispest and Pestszentlörinc associations, for instance, operated with the help of membership fees and donations from the locals, the latter being a very significant source of support in a small, bourgeois neighborhood. There were, however, no patrons as important and influential as Alfréd Brüll at MTK in Budapest. The clubs often organized balls and dances in order to strengthen the union of their members, to promote sports life, and, (last but not least) to improve their financial condition. These events were usually organized in local restaurants. Several clubs did not even have headquarters and instead chose one of the restaurants. Restaurants became home to club life by being the location for both informal meetings and official consultations. Béla Mayer, both a founder of KAC (KISPEST Athletic Club) and its team administrator, often had consulting hours in cafés and restaurants (Nemzeti Sport 1943, Dec. 12).

Most lower-middle-class and working-class boys in towns played football all day long on empty sites. They dreamed of becoming players as famous as their idols were. These boys were extremely happy if some club members or managers invited them for a trial match, and they became even more agitated when they were invited to join the pre-junior team and were given a precious but old and overwashed home shirt worn by a well-known player from the club's first division team (Buzánszky 2010). These boys were well aware of the fact that success was very difficult to achieve. They knew about the strict hierarchy and discipline of the changing rooms. It was commonplace that younger players would formally address team members 8-10 year older than they. As part of the reception-integration ritual, younger members were sent for spritzers and felt honored when they were asked to clean an experienced player's shoes. Young people accepted this hierarchy as a necessity to reserve a position and to develop and to take root in the team (Borsi-Kálmán 2008, pp. 97-98). Their ambition was to become distinctive footballers and to be selected to join the National Eleven; what is more, to live an easier life.

There is a well-known story about young Puskás from the time when the Kispest team arrived in Kolozsvár". "Öcsi was carrying the luggage for the 10-year older, right back defender named Károly I. Olajkár, once member of the National Eleven." Such cases were not unique but rather common. And even Puskás had to obey these hierarchical rules. He was fortunate to be able to integrate more quickly, as his

\footnotetext{
${ }^{7}$ It happened during the 1943-44 championship, when “Öcsi” was only 17.
} 
talent was soon acknowledged and, thanks to his football coach father, he could avoid the most inconvenient side effects of the changing room hierarchy.

It's worthwhile to pay more attention to the objective contents that are preserved by contemporary photos, though the subjective contents of memory should not be neglected.

\section{Methods}

The values of using photographs as research source material are listed by Mietzner and Pilarczyk (2010, p. 7):

"a photograph preserves - apart from the photographed event itself - the common, quotidian elements of life, the unimportant, ritualized, commonplace details, the involuntary body postures and gestures, which are supposed to be so profane that we tend to forget about them (e.g. the appearance of the room, facial expressions, gestures)".

The iconographical (culture-anthropological) approach used in this article (Géczi 2008, 2009, 2010, Sztompka 2009) differentiates between three anthropological domains. The first level represents the appearance and body features people in the photo have (e.g. face, hair, clothing, cap, etc.). The second level comprises the immediate environment of the first level, the environment in which the bodies can be seen and the possible actions take place. The third level, which is a broader environment than the previous ones, is the territory of life of the people depicted by the photo, where occurrences of their life take place.

The three anthropological levels are discussed in the framework of Erwin Panofsky's iconographic methodology (1984) consisting of four strata. The first (1. Preliminary iconographic description] is the most basic level of primary, natural subject matter: the creation of a text about everything that can be seen and perceived in the picture. The identified picture elements - no matter whether their inclusion was intentional or not by the author - are transformed into words in an objective description.

The next stratum (2. Iconographic description] reveals the context in which the photo was taken. This description is placed into the typology of patterns such and similar photos usually employ. The primary analysis starts at this level, where some common aspects can emerge and should be checked.

The third stratum (3. Iconographic interpretation] considers secondary, implicit, and intrinsic content and symbols employed by the author.

The fourth stratum (4. Iconological interpretation] is the study of deeply underlying, tertiary, intrinsic meanings (both intentional and unintentional).

"While in the first two stages the manifest in the last two stages the latent content is investigated" (Géczi 2010, p. 128).

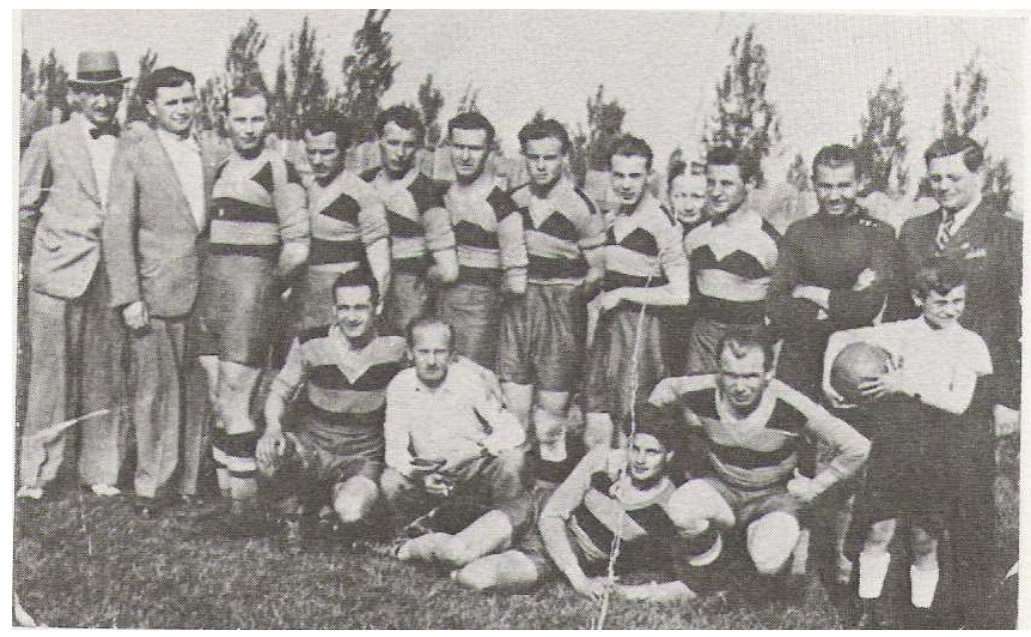

Photo 1. Deák with the SZAC first division team

Source: Pongrácz, 1992, p. 165
Our analysis starts with the photo related to Ferenc Deák.

We can see 17 people in the photograph in two rows. There are more people in the back row (12), while five can be found in the front. Eleven of them are in sportswear: 10 are in identical clothes, wearing transversely striped home shirts and dark shorts. One differs in the color of his home shirt, which is the same color as that of his shorts. Of the five people in sportswear, we can also see soccer socks. Six persons are in street clothes: three are in suits; one of them 
also has a hat on. Two men in suits are wearing neckties, too. The man with the hat sports a bow tie, while the other one has a regular tie and a matching decorative handkerchief in the top pocket of his jacket. The fourth man is wearing a white shirt and trousers, whereas we can only see the face of the fifth. Judging from his build, the sixth is a child who is wearing a white, short-sleeved shirt, dark shorts, white knee socks, and dark ankle boots.

The people in the photo form a single group. The ones in street clothes also belong to the group, as their position suggests. They are standing at both ends of the back row: two of them are at the left, while only one man in a suit can be found at the right end. On the right we can see a face between the fourth and fifth persons in street clothes, presumably wearing similar clothes (as his position might suggest). Out of the five persons in the front row there are two in street clothes: the man on the left wearing a shirt and trousers between the first and the third persons in sports clothes, as is the child on the right. Each man in sportswear has a swept-back hairstyle. One suit-wearing man's hair is not visible due to his hat, while the other two part their hair on the left. The man with the hat differs from the rest in that he is sporting a moustache while the others have clean-shaven faces.

As seen from their traditional clothes and sportswear, the people that form the group are all men (one of them is still a boy). There are trees of various sizes in the background; they form a line. On the basis of their shape and position they must be poplars; in front of them there is an arch fence spanning from the left side of the picture to the right.

Everybody is standing in the back row, while three people are squatting in the front row, one is lying on the ground, and the only one standing is a little boy holding a leather ball under his arm. Unlike the others, he is looking away, at something other than the camera. The ones in the front are all looking straight into the camera lens, whereas only two-thirds in the back row are doing the same. Out of those who do not have their eyes fixed on the camera two are looking in front of themselves, two are looking sideways. The clothes of the majority indicate that the photograph is related to a sports event. It can be seen from the sportswear (especially from the condition of the athletic socks) that the picture was taken after the event. The photo caption reveals that it was taken of the SZAC adult team after a victorious match on May 18, 1941. From this date it follows that the team members were wearing the black-blue striped home shirt of the club (with the blue seen as grey in the black-and-white photograph). In all probability every sportsman was wearing soccer socks and shoes (despite the fact that several feet are not visible).

For taking photos of football teams, it was common to invite civilians (president, administrative manager, coach, even children, etc.) to pose for the photo. This photo also followed the tradition. Civilians standing at both sides of the picture include the butcher János Danninger, a patron of the team. The other gentleman, with a decorative handkerchief in his jacket, is Árpád Árky, executive president. He was known to dress elegantly; he always wore a suit, a necktie, and a white shirt to work (Muraközi 2011). His consciousness as a skilled worker must have been very strong (Gáspár 220, pp. 40-41). He was a printer by profession and as a tradesman, he sympathized with the Social Democrats. As the executive manager of the club his duties were to organize and prepare matches, to provide the club with financial sources, to do the bookkeeping (Torma 2002).

The photo was taken on the SZAC football field because the team played at home at that time. The group was formed with the intention to have this photo taken but the arrangement of the people in it is slightly disorganized, which may mean that there was no professional photographer present. The first five players on the left are posing in a more or less unified fashion: they put their hands behind their backs and turn to the camera with their left shoulders. The rest of the players are not so well organized: the sixth player's hands are in the front and the seventh faces the camera lens nearly fully, the eighth (the goalkeeper in the different home shirt) with his chest. The goalkeeper also crosses his arms. The three squatting men did not take a unitary position either; what is more, a civilian can also be seen among them. One player is leisurely lying on the ground in the front, a posture typical of team photos, but it is usually organized symmetrically in most photos with one more person lying on the opposite side. 
Many of the participants are smiling and are cheerful in the picture; they are probably happy about their victory. Some are winking in the sunshine but all of them are looking straight into the camera lens, except for two sportsmen, two civilians, and the little boy, who is looking in a different direction, perhaps at one of his relatives. The photo itself is not so important for him; he is delighted with being able to hold the ball in his hands.

Deák ("Bamba") is in a focused position on the photo, as he is the only figure lying down, what is more, in the foreground of the picture. He is a tall, well-built, 19-year-old young man. If he were standing, he would reach even higher than János Danninger's hat. His position suggests that he has to look upwards into the camera; his facial features reveal satisfaction and pride. He is resting comfortably on his left elbow and he is radiating contentment. And he could be really proud of himself that day, as he had played in the first division team, the team had won, and he had scored three goals. From the latter information we can also conclude that he had been playing very well during the match that day.

We can see a vertical breakline in the photo obscuring Deák's face and body. This feature also contributes to our attention being drawn to the center striker. If we had no knowledge about the outcome of the match, we could not name the best striker of the day by simply looking at the photo. However, we could surely recognize the most satisfied player.

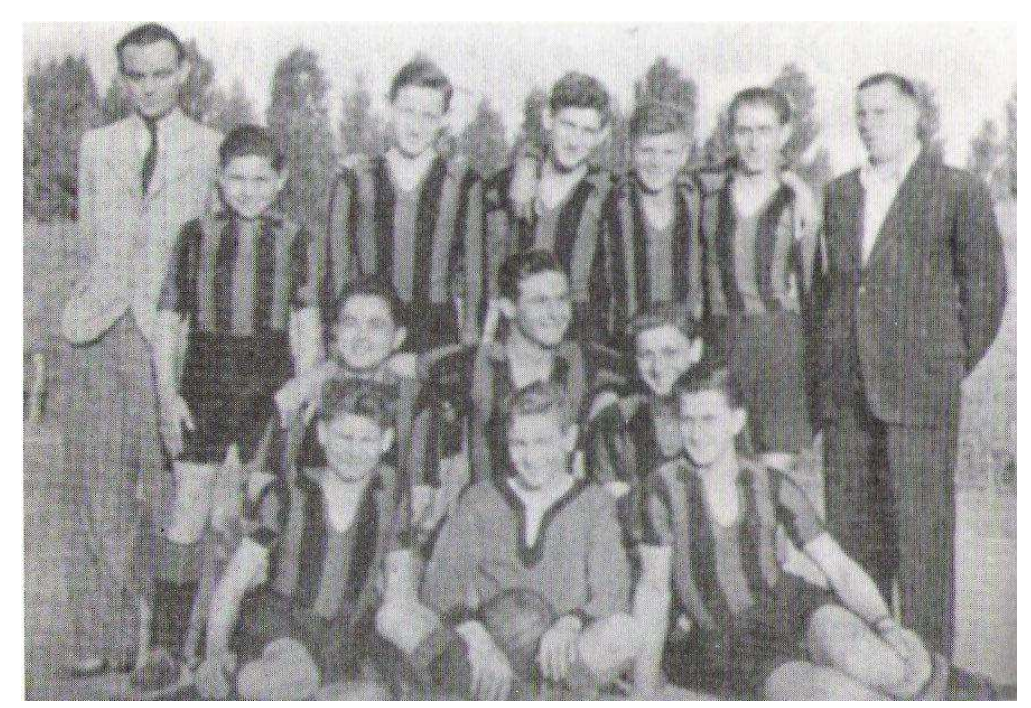

Photo 2. Puskás and the KAC junior team

Source: Hámori 2001, pp. 180

The photo depicts thirteen persons sitting and standing in three lines. In the first and middle lines, there are three persons per line; in the back line, there are seven persons. Eleven persons are wearing sportswear; ten of them are wearing identical clothing: a home shirt with lengthwise stripes and dark shorts. The eleventh person differs from the other ten players only in the colour of his home shirt. All home shirts - except for one have got a V-cut neckline. On four people in sportswear we can also see soccer socks.

Two persons are dressed in street clothes: both of them are wearing suits, and one of them has a necktie on, too. This latter man is wearing a pair of checkered trousers and a light colored (also checkered) jacket, while the other man has a dark suit on. All persons in the picture form a group. Two civilians belong to the group as well, who are standing at the right and left side of the back line. Nearly half of the members of the group part their hair on the side and half of them have swept back hairstyle. The persons in sportswear are children or youngsters, as their appearance suggests, whereas the persons wearing suits are adults. Neither of the group members have facial hair. The people in the picture are all men, as their traditional clothing and sportswear suggest.

In the background, we can see trees, which must be evergreens, based on their shape. The photo was taken outdoors probably at a sports ground. The persons in the first row are sitting on the ground, those in the second row are squatting, whereas the players in the third row are standing. Two of the football players in the front are sitting sideways surrounding the goalkeeper (who is the only one in a different home shirt) with the leather ball in his lap. The squatting players can be seen from chest upwards, and most of the players standing in the back row can be seen from waist upwards, while you can see whole bodies of the two adults and the youngest boy. The two adults and one of the boys look serious; the others are smiling. The boy sitting in the middle of the squatting group is not looking straight into the camera lens, nor is the man on the 
left. The former is looking at something other than the camera, or he is telling a joke to the boy next to him. The latter boy is staring at the ground.

The photo caption reveals the names of two persons: "Öcsi" (Puskás) and his father, which means that it is a picture of the football team KAC. Consequently, the players must be wearing black-and-red home shirts. The ball on the goalkeeper's lap also hints that these sportsmen play football. The photo was probably taken at AC sports ground of Kispest. The civilians and the players form a unitary group, as they all belong to this same sports club.

Based on the arrangement of the group (the symmetry of the two persons sitting sideways in the first row, inserting the middle row, and the adults arranged on both sides of the persons standing in the back row), we can assume that the photo was taken by a professional photographer. We do not know which sports event the photo is trying to depict, but it is obvious that the boys are cheerful and confident. The boy in the middle of the squatting row in the center of the picture is apparently one of the strongest and biggest in the group. $\mathrm{He}$ is putting his arms around the shoulders of the boys next to him, which may have been the photographer's instruction, but it may have been a spontaneous idea as well. The boy in the middle may have made a comment in connection with what was happening, which is why he is looking in a different direction and not straight into the camera lens. The same can be concluded from the fact that the players next to him are not just smiling but are laughing with open mouths.

One of the boys standing in the back row - "Öcsi" - copies the gestures of the squatting boy. He is putting his arms on the shoulders of the two boys next to him too, but he is smaller, and his arms are shorter than those of the boy in the middle. Therefore, the scene conveys the impression that he is hanging on his mates rather than putting his arms around their shoulders. One boy is leaning towards Puskás, while the neck of the other boy is tensing up, because he is resisting the pulling power.

"Öcsi's" gestures were probably not suggested by the photographer, because it disrupted the order of the arrangement. Puskás's mischievous smile may even refer to the fact that the boys are making jokes, they are trying to bring something new into the situation, something that is connected to them. This may express their opposition to external instructions. On the other hand, their skilled movements remind us of the essence of their lives, i.e. football and dribbling. All in all, the boys give the impression that there is not a moment of peace around them; they are always ready to play tricks either while playing a match or in civil life.

The seriousness of Ferenc Puskás (the father) stands in contrast to the delight and happiness of the boys; but being their coach he felt responsible for persuading the boys to do their best. According to his daughter, when he was asked about his son's prospects as a footballer, he just waved his hand and said that "Öcsi" was too lazy to become a good player. But the real aim of his words was to fuel his son's willpower, desperation, and ambition (Almási 2009). Young Puskás recalls these memories of his father in his biography saying that " Öcsi' was running and training all the time; from tree to tree, from corner to corner, to school, and after the tram. He wanted to become a football player" (Almási 2009). His willpower and desperation was meant to accomplish his goal of becoming a good football player. And the first step to reach his goal was being a member of the KAC junior team sporting their black-and-red home shirt (see photo). The next step was soon to come: he was invited to play on the adult team ${ }^{8}$ and later on (as the third step) in the National Eleven.

\footnotetext{
${ }^{8}$ After his first match with the adult team, he gave his first interview to a reporter from Nemzeti Sport. His answer to the question "What is it like playing among 'old' men?", the 16-year-old boy answered: "I do not feel like saying anything right now". He meant that the interview was taking precious time from the game. Later on he added that the only difference he felt was that the adult game was much faster and more tiring, but he also added: "it is not a problem as we, juniors are constantly training, we are playing on the playground all day long in good weather." He answered the reporter's next question "Where is it better to play a match: on the playground or on the football pitch?" by expressing his preference for the playground (Nemzeti Sport, 4.12.1943 - cited in Borsi-Kálmán, 2008, pp. 98-99). Puskás did not realize the great honor for being allowed to play with the "experts"; playing football was his natural medium.
} 


\section{Conclusions from the analysis of the photos}

A common feature of the photos is that they were taken outdoors, on the sports ground, in the company of team members and other people related to the team. This environment was highly important in the lives of both Puskás and Deák; their whole career justifies the priority of sports.

Their gestures and postures ("Bamba's" posture lying on the ground and "Öcsi's" smile into the camera lens) directly refer to the fact that both footballers are very keen on being part of the events that the photos captured. They feel happy and comfortable. The aforementioned gestures place them into the center of attention. "Bamba's" posture was probably spontaneous while "Öcsi's" must have been deliberate, as he always managed to focus attention on himself. Humor played a mayor role in Puskás' life: he used it very often to become the center of the actual group of people.

Both players wore the home shirt of their clubs with pride, as they strongly believed that this uniform symbolizes the team, the club, the sport of football, and even the spectators, who only implicitly took part in the game. In the background of their pride, the fact is also present that they managed to enter to the sports club from the sandlot and that way they got closer to realizing their biggest dream: to be a football player as popular as their icons. This didn't just mean a sports career for them. It meant an emergence from their social environment, a better life.

Both of them look definitely happy and cheerful in the photos. This state is not just temporary. On the contrary, it implies a permanent feature of their characters: the pleasure that playing football could give them. Football that proved to shape their fate.

\section{REFERENCES}

Almási, T. (2009). Puskás Hungary. (Biographical movie) 116' Filmplus Filmgyártó Kft.

Borsi-Kálmán, B. (2008). Az aranycsapat és a kapitánya /The golden team and its captain/. Budapest: Kortárs Könyvkiadói Kft.

Buzánszky, J. (- personal account, 2010). Beszélgetés Buzánszky Jenő labdarúgóval, az Aranycsapat tagjával /Interview with football player Jenö Buzánszky, member of the "Magical Magyars"/. Veszprém, 03/11/2010.

Cartledge, B. (2009). The peace conference of 1919-23 and its aftermath. Mihály Károlyi \& István Bethlen. Haus Publishing Ltd., London.

Gáspár, S. (- personal account). Made by Kozák Márton in 1989-1990. Oral History Archives of 1956 Institut. No 220.

Géczi, J. (2008). Ikonológia-ikonográfia mint a történeti pedagógia segédtudománya. (Iconograpic-iconological Analysis as a Second-science of Historical Pedagogy) In B. Pukánszky (Ed.), A neveléstörténet-írás új útjai /The New Ways of Historical Pedagogy. (pp. 180-190). Gondolat Kiadó, Budapest,.

Géczi, J. - Darvai, T. (2011): Iconographic examination of the photos in journal "Tanító" ("Teacher"). History of Education \& Children's Literature, VI. 2 (2011) pp. 187-202.

Géczi, J. (2010). Sajtó, kép, neveléstörténet. Tanulmányok /The Press, picture and history of education. Studies/. Veszprém - Budapest: Iskolakultúra.

Glatz, F. (2003). Futball és történetírás. /Soccer and histography/. História, 8-9.

Hadas, M., Karády, V. (1995). Futball és társadalmi identitás. /Soccer and social identity/ Replika, 17/18, 89-121.

Hámori, T. (2001). Puskás Öcsi. A leghíresebb magyar története /"Öcsi” Puskas. Story of the most famous Hungarian/. Budapest: Pharma Press Nyomdaipari Kft.

Horváth, H.A. (2010). Aranyló rongylabda. Fragmentumok a magyar foci virágkoráról /Golden ball: fragments from the peak time of Hungarian football/. Iskolakultúra, 2010/02, 127-134.

Horváth, H.A. (2011). Informális tanulás az Aranycsapat korában /Informal learning in the age of "Magical Magyars"/. Budapest: Gondolat Kiadó.

Mietzner, U., Pilarczyk, U. (2008). Bilder als Quellen in der erziehunghistorischen Forschung /Picture as Source in the Educational Research/. In B. Pukánszky (Ed), A neveléstörténet-írás új útjai /New Ways of Educational History Writing/(pp. 194-213). Budapest: Gondolat Kiadó.

Mietzner, U., Pilarczyk, U. (2010). A képtudomány módszerei a neveléstudományi és a társadalomtudományi kutatásban /Methods of Image Analysis in Research in Educational and Social Sciences/. Iskolakultúra, 5-6, 3-20. 
Muraközy. T. (- personal account, 2011). Made by Horváth, H. A. MP3 fájl a készítő gyüjteményében.

Panofsky, E. (1984). A képzőművészeti alkotások leírásának és tartalomelemzésének problémájához /The fine art of description and content analysis of the problem/. In A jelentés a vizuális müvészetekben /Meaning in the Visual Arts/ (pp. 249-261). Budapest: Gondolat.

Pongrácz, G. (1992). A Bamba. Minden idők legnagyobb gólkirályáról. Deák Ferenc életregénye /The "Bamba”. The biggest goalscorer of all time. Biographical novel of Ferenc Deák/. Budapest: SZAC.

Romsics, I. (2005). Magyarország története a XX. században /The history of Hungary in the $20^{\text {th }}$ century/. Budapest: Osiris.

Sztompka, P. (2009). Vizuális szociológia /Visual Sociology/. Budapest: Gondolat Kiadó.

Torma, I. (2002). Adalékok a 100 éves SZAC történetéhez /Additional information to the History of 100 Years Old SZAC/. Kézirat.

AUTHOR'S ADDRESS:

Attila Horváth H.

1183 Budapest

Árpád u. 13/a

Hungary

Email: hha@almos.vein.hu 